\title{
Polymeric Microsphere Dosage Form
}

National Cancer Institute

\section{Source}

National Cancer Institute. Polymeric Microsphere Dosage Form. NCI Thesaurus. Code C42736.

Polymeric microspheres composed of biocompatible polymer that contains active and/or inert ing redient(s) designed for release at a controlled rate. 